\title{
Facile Synthesis of Two Azete-Steroid Derivatives and Theoretical Evaluation of Its Interaction with the Aromatase Enzyme
}

\section{İki Azete Steroid Türevinin Basit Sentezi ve Aromataz Enzimi ile Etkileşiminin Teorik Olarak Değerlendirilmesi}

Figueroa-Valverde Lauro ${ }^{1}$, Diaz-Cedillo Francisco ${ }^{2}$, Rosas-Nexticapa Marcela ${ }^{3}$, Garcimarero-Espino E. Alejandra $^{4}$, Mateu-Armand Virginia ${ }^{3}$, Hernandez-Vazquez Patricia ${ }^{3}$, Benitez-Coeto Laura ${ }^{3}$, Pool Gómez Eduardo $^{1}$, Lopez-Ramos Maria ${ }^{1}$, Hau-Heredia-Lenin ${ }^{1}{ }^{1}$, Borges-Ballote Yaritza ${ }^{1}$

${ }^{1}$ Laboratory of Pharmaco-Chemistry at the Faculty of Chemical Biological Sciences of the University Autonomous of Campeche, Av. Agustín Melgar s/n, Col Buenavista C.P.24039 Campeche Cam., México.

${ }^{2}$ Escuela Nacional de Ciencias Biológicas del Instituto Politécnico Nacional. Prol. Carpio y Plan de Ayala s/n Col. Santo Tomas, México.

${ }^{3}$ Facultad de Nutrición, Universidad Veracruzana. Médicos y Odontólogos s/n, 91010, Xalapa, Veracruz. México.

${ }^{4}$ Facultad de Medicine, Universidad Veracruzana. Médicos y Odontólogos s/n, 91010, Xalapa, Veracruz. México.

\section{ABSTRACT}

everal aromatase inhibitors have used for the treatment of breast cancer; however, some of these drugs may produce some side effects such as endometrial cancer and bone loss. The aim of this study was to synthesize two new azete-steroid derivatives (compounds 9 or 10) to evaluate its theoretical interaction with an aromatase enzyme (2wd3) using anastrozole and exemestane as controls in a docking model. The preparation of 9 and 10 was carried out using a series of reactions which involves amination, etherification, nitration, and addition. Chemical structure of the compounds was confirmed using elemental analysis and NMR spectrum. The results showed that compounds 9 or 10 could bind to a different type of aminoacid residues involved in of $2 \mathrm{wd} 3$ protein surface compared anastrozole and exemestane; this phenomenon may exert changes in the biological activity of aromatase enzyme. All data suggest that compounds 9 or 10 could be an alternative for the treatment of breast cancer; therefore it could be a good candidate for the pharmaceutical industry.

\section{Key Words}

Azete, steroid, derivative, docking model.

\section{öz}

M eme kanserinin tedavisi için birkaç aromataz inhibitörü kullanılmıştır; ancak, bu ilaçların bazıları endometrial kanser ve ke mik kaybı gibi bazı yan etkiler yaratabilir. Bu çalışmanın amacı, bir yerleştirme modelinde kontroller olarak anastrozol ve exemestan kullanarak teorik etkileşimini bir aromataz enzimi (2wd3) ile teorik etkileşimini değerlendirmek için iki yeni azete-steroid türevini (bileşik 9 veya 10) sentezlemekti. 9 ve 10'un hazırlanması, aminasyon, eterleştirme, nitrasyon ve ekleme içeren bir dizi reaksiyon kullanılarak gerçekleştirildi. Bileşiklerin kimyasal yapısı element analizi ve NMR spektrumu kullanılarak doğrulandı. Sonuçlar, bileşikler 9 veya 10'un, anastrozol ve exemestan ile karşılaştırıldığında 2wd3 protein yüzeyinde yer alan farklı tipte bir amino asit tortusuna bağlanabileceğini gösterdi; bu fenomen, aromataz enziminin biyolojik aktivitesinde değişiklikler yapabilir. Tüm veriler, bileşik 9 veya 10'un, meme kanseri tedavisinde bir alternatif olabileceğini göstermektedir; bu nedenle ilaç endüstrisi için iyi bir aday olabilir.

\section{Anahtar Kelimeler}

Azete, steroid, türev, yerleştirme modeli.

Article History: Received: May 5, 2019; Revised: Jul 15, 2019; Accepted: Sep 10, 2019; Available Online: Nov 1, 2019.

DOI: https://doi.org/10.15671/hjbc.602183

Correspondence to: Figueroa-Valverde Lauro, Laboratory of Pharmacochemistry, University Autonomous of Campeche, Mexico.

E-Mail: lauro_1999@yahooo.com 


\section{INTRODUCTION}

is here are studies which indicate that breast cancer is one of the main health problems worldwide [14]. It is noteworthy that some drugs have been used to treatment of breast cancer such as tamoxifen (estrogen-receptor antagonist) [5], anastrozole, letrozole or exemestane (aromatase inhibitors) [6-8], fisetin or methyl paraben (17-hydroxy dehydrogenase type 1 inhibitors) [9, 10]; however, some of these drugs may produce some adverse effects such as secondary endometrial cancer [11] and bone loss [12]. In the search of new pharmacological treatment to breast cancer, some drugs have been developed; for example, the asymmetric synthesis of a piperidine derivative via an organocatalytic Michael-Henry reaction with biological activity against breast cancer in vitro [13]. In addition, a study showed the preparation of nimesulide from 2-Amino5-nitro-phenol as a breast cancer inhibitor using SKBR-3 cells [14]. Also, a series of dienone-derivatives were synthesized from oridonin which exerted effects against breast cancer in vitro [15]. Other study showed reaction of 4-(dimeth-ylamino)benzaldehyde with N-(3Acetyl-2-hydroxy-phenyl)-acetamide to form 8-Amino4'-(dimethylamino)flavone and their biological activity against breast cancer on MCF-7 cells [16]. It is important to mention, that some theoretical models have been used to characterize the interaction of drugs with some biomolecules involved in breast cancer; for example, a theoretical analysis showed the interaction plumbaginhydrazine (breast cancer inhibitor) with NF-KB (nuclear factor kappa-light-chain-enhancer of activated B cells) using a Docking model [17], Additionally, other report showed the interaction of tamoxifen, raloxifene, toremifene (breast cancer inhibitors) with estrogen receptor using the HEX-docking software [18]. Other data showed that some estrone derivatives can produce apoptosis of breast cancer cells via carbonic anhydrase IX inhibition using Autodock program [19]. All these data indicate that several drugs could exert effects on breast cancer; however, their interaction with several targets biological is confusing, this phenomenon could be due to the different chemical structures of each drug or to protocols used. Analyzing these data, the aim of this study was to synthetize two azete-steroid derivatives were prepared and their theoretical activity on aromatase enzyme was evaluated using a DockingServer model.

\section{MATERIALS and METHODS}

\subsection{General methods}

The reagents involved in this investigation were purchased from Sigma-Aldrich Sigma-Aldrich Co., Ltd. The melting point for compounds was determinate using an Electrothermal (900 model). Infrared spectra (IR) were evaluated using i50 FT-IR Nicolet spectrometer. ${ }^{1} \mathrm{H}$ and ${ }^{13} \mathrm{C}$ NMR (nuclear magnetic resonance) spectra were determinate with a Varian VXR300/5 FT NMR spectrometer at $300 \mathrm{MHz}$ (megahertz) in $\mathrm{CDCl}_{3}$ (deuterated chloroform). EIMS (electron impact mass spectroscopy) spectra were evaluated using a Finnigan Trace Gas Chromatography Polaris Q-Spectrometer. Elementary analysis data were evaluated from a Perkin Elmer Ser. II CHNS/02400 elemental analyzer.

\section{Chemical Synthesis \\ Amination}

In a round bottom flask $(10 \mathrm{ml})$, 2-nitroestrone or 2-nitroestradiol $(0.50 \mathrm{mmol}), 3$-Ethynylanyline $(60 \mu \mathrm{l} 0.53$ $\mathrm{mmol}$ ) and $5 \mathrm{ml}$ of formaldehyde were stirred to reflux for $12 \mathrm{~h}$. The mixture was purified via a crystallization using the methanol:water (4:1) system.

\section{4-[(3-Ethynyl-phenylamino)-methyl]-3-hydroxy-13- methyl-2-nitro-6,7,8,9,11,12,13,14,15,16-decahydro- cyclopenta[a]phenanthren-17-one (3)}

yielding $44 \%$ of product; m.p. $43-45^{\circ} \mathrm{C}$; IR (vmax, $\left.\mathrm{cm}^{-1}\right)$ 3402, 3312, 2102, 1712 and 1352: ${ }^{1} \mathrm{H}$ NMR $(300 \mathrm{MHz}$, Chloroform-d) $\delta_{H}: 0.93(\mathrm{~s}, 3 \mathrm{H}), 1.20-1.90(\mathrm{~m}, 7 \mathrm{H}), 2.12-$ $2.50(7 \mathrm{H}), 2.82(\mathrm{~s}, 1 \mathrm{H}), 3.01(\mathrm{~m}, 1 \mathrm{H}), 4.40(\mathrm{~m}, 2 \mathrm{H}), 6.56-$ $7.12(\mathrm{~m}, 4 \mathrm{H}), 7.16(\mathrm{~m}, 1 \mathrm{H}), 9.10$ (broad, $2 \mathrm{H}) \mathrm{ppm} .{ }^{13} \mathrm{C}$ NMR $\left(300 \mathrm{~Hz}, \mathrm{CDCl}_{3}\right) \delta_{\mathrm{c}}: 13.9,21.6,25.4,27.4,28.0$, 30.8 , 34.6, 37.2, 42.3, 47.9, 48.4, 50.4, 78.2, 84.0, $113.1,122.5,122.7,123.5,125.0,125.0,129.8,134.3$, 136.6, 145.4, 146.7, 147.1, 219.8 ppm. El-MS m/z: 444.53. Anal. Calcd. for $\mathrm{C}_{27} \mathrm{H}_{28} \mathrm{~N}_{2} \mathrm{O}_{4}: \mathrm{C}, 72.95 ; \mathrm{H}, 6.35 ; \mathrm{N}$, 6.30; O, 14.40. Found: C, 72.90; H, 6.28.

\section{4-[(3-Ethynyl-phenylamino)-methyl]-13-me- thyl- 2-nitro-7,8,9,11,12,13,14,15,16,17-deca- hydro-6H- cyclopenta[a]phenanthrene-3,17-diol (4)}

yielding $56 \%$ of product; m.p. $58-60^{\circ} \mathrm{C}$; IR (vmax, cm $\left.{ }^{1}\right)$ 3400, 3310, 2102 and 1350: ${ }^{1} \mathrm{H}$ NMR $(300 \mathrm{MHz}$, Chloroform-d) $\delta_{H}: 0.64(\mathrm{~s}, 3 \mathrm{H}), 0.80-1.86(\mathrm{~m}, 11 \mathrm{H}), 2.12-$ $2.52(\mathrm{~m}, 3 \mathrm{H}), 2.84(\mathrm{~s}, 1 \mathrm{H}), 2.94-3.64(\mathrm{~m}, 2 \mathrm{H}), 4.40(\mathrm{~m}, 2 \mathrm{H})$, 6.62-7.10 (m, 4H), $7.64(\mathrm{~m}, 1 \mathrm{H}), 8.20$ (broad, 3H) ppm. ${ }^{13} \mathrm{C} \mathrm{NMR}\left(300 \mathrm{~Hz}, \mathrm{CDCl}_{3}\right) \delta_{\mathrm{C}}: 15.8,24.2,25.3,27.7,28.0$, 
32.7, 33.7, 37.2, 42.3, 44.4, 45.1, 50.7, 78.2, 82.4, 84.01, $113.1,122.4,122.7,123.5,125.0,125.3,129.8,134.8$, 136.6, 145.4, 147.0, 147.1 ppm. El-MS m/z: 446.22. Anal. Calcd. for $\mathrm{C}_{27} \mathrm{H}_{30} \mathrm{~N}_{2} \mathrm{O}_{4}: \mathrm{C}, 72.62 ; \mathrm{H}, 6.77 ; \mathrm{N}, 6.27 ; \mathrm{O}$, 14.33. Found: $C, 72.58 ; H, 6.70$.

\section{Etherification}

In a round bottom flask $(10 \mathrm{ml})$, compounds 3 or $4(0.50$ $\mathrm{mmol})$, potassium carbonate $(60 \mathrm{mg}, 0.43) 5 \mathrm{ml}$ of dimethyl sulfoxide were stirred to reflux for $6 \mathrm{~h}$. The solvent of mixture was reduced pressure and purified via a crystallization using the methanol:water (4:1) system.

\section{4-[(3-Ethynyl-phenylamino)-methyl]-13-methyl- $6,7,8,9,11,12,13,14,15,16$-decahydro-20-oxa- cyclopropa[2,3]cyclopenta[a]phenan- thren-17-one (5)} yielding $38 \%$ of product; m.p. $76-78^{\circ} \mathrm{C}$; IR (vmax, $\mathrm{cm}^{-1}$ ) 3310, 2104, 1712 and 1242: ${ }^{1} \mathrm{H}$ NMR (300 MHz, Chloroform-d) $\delta_{H}: 0.90(\mathrm{~s}, 3 \mathrm{H}), 1.20-1.92(\mathrm{~m}, 7 \mathrm{H}), 2.12-$ $2.54(\mathrm{~m}, 8 \mathrm{H}), 2.88(\mathrm{~s}, 1 \mathrm{H}), 4.48(\mathrm{~m}, 2 \mathrm{H}), 4.73$ (broad, $1 \mathrm{H})$, $6.22(\mathrm{~m}, 1 \mathrm{H}), 6.62-7.16(\mathrm{~m}, 4 \mathrm{H}) \mathrm{ppm} .13 .8,21.7,25.7$, $27.4,28.0,31.3,35.1,37.5,38.3,47.4,48.2,50.5,78.2$, $84.0,109.8,113.1,118.3,122.5,122.7,125.0,129.8$, 131.9, 133.1, 143.6, 147.4, 148.5, 220.7 ppm. El-MS m/z: 397.20. Anal. Calcd. for $\mathrm{C}_{27} \mathrm{H}_{27} \mathrm{NO}_{2}: \mathrm{C}, 81.58 ; \mathrm{H}, 6.85 ; \mathrm{N}$, 3.52; O, 8.05. Found: C, 81.50; H, 6.80.

\section{4-[(3-Ethynyl-phenylamino)-methyl]-13-methyl- $6,8,9,11,12,13,14,15,16,17$-decahydro-7H-20-oxa-} cyclopropa[2,3]cyclopenta[a]phe- nanthren-17-ol (6) yielding $45 \%$ of product; m.p. $84-86^{\circ} \mathrm{C}$; IR (vmax, $\mathrm{cm}^{-1}$ ) 3400, 3312, 2102 and 1240: ${ }^{1} \mathrm{H}$ NMR (300 MHz, Chloroform-d) $\delta_{H}: 0.76(\mathrm{~s}, 3 \mathrm{H}), 0.82-1.88(\mathrm{~m}, 11 \mathrm{H}), 2.12-$ $2.54(\mathrm{~m}, 4 \mathrm{H}), 2.88(\mathrm{~s}, 1 \mathrm{H}), 3.64(\mathrm{~m}, 1 \mathrm{H}), 4.48(\mathrm{~m}, 2 \mathrm{H})$, 5.58 (broad, $2 \mathrm{H}), 6.16(\mathrm{~m}, 1 \mathrm{H}), 6.62-7.16(\mathrm{~m}, 4 \mathrm{H}) \mathrm{ppm}$. $15.8,24.2,25.3,27.7,28.0,32.7,33.7,37.2$, 38.3, 44.4, $44.6,50.7,78.2,82.4,84.0,110.2,113.1,118.3,122.5$, 122.7, 125.0, 129.8, 132.3, 133.5, 143.6, 147.4, 148.5 ppm. El-MS m/z: 399.21. Anal. Calcd. for $\mathrm{C}_{27} \mathrm{H}_{29} \mathrm{NO}_{2}$ : C, 81.17; H, 7.32; N, 3.51; O, 8.01. Found: C, 81.12; H, 7.30.

\section{Nitration}

In a round bottom flask $(10 \mathrm{ml})$, compounds 5 or $6(0.50$ $\mathrm{mmol}), 5 \mathrm{ml}$ of anhydride acetic and $1 \mathrm{ml}$ of nitric acid were stirred to reflux for $6 \mathrm{~h}$. The solvent of mixture was reduced pressure and purified via a crystallization using the methanol:hexane:water (4:2:1) system.
4-[(3-Ethynyl-2,4,5,6-tetranitro-phenylamino)-methyl]-13-methyl-1-nitro-6,7,8,9,11, 12,13,14,15,16-decahydro-20-oxa-cyclopro- pa[2,3] cyclopenta[a]phenanthren-17-one (7)

yielding $66 \%$ of product; m.p. $122-124^{\circ} \mathrm{C}$; IR (vmax, $\mathrm{cm}^{-1}$ ) 3312, 1244, 1712 and 1352: ${ }^{1} \mathrm{H}$ NMR (300 MHz, Chloroform-d) $\delta_{H}: 0.92(\mathrm{~s}, 3 \mathrm{H}), 1.20-1.91(\mathrm{~m}, 7 \mathrm{H}), 2.12-$ 3.00. $(\mathrm{m}, 15 \mathrm{H}), 3.90(\mathrm{~s}, 1 \mathrm{H}), 4.84(\mathrm{~m}, 2 \mathrm{H}), 9.92$ (broad, 1H) ppm. ${ }^{13} \mathrm{C} \mathrm{NMR}\left(300 \mathrm{~Hz}, \mathrm{CDCl}_{3}\right) \delta_{\mathrm{C}}: 13.8 .21 .7,27.4$, 28.1, 30.0, 31.3, 35.3, 37.7, 42.3, 45.2, 48.1, 50.2, 71.0, 79.7, 115.2, 125.1, 126.2, 128.5, 130.2, 132.5, 134.4, 135.1, 136.3, 136.5, 141.9, 142.3, 220.3 ppm. El-MS m/z: 6.22.12. Anal. Calcd. for $\mathrm{C}_{27} \mathrm{H}_{22} \mathrm{~N}_{6} \mathrm{O}_{12}: \mathrm{C}, 52.09 ; \mathrm{H}, 3.56 ; \mathrm{N}$, 13.50; O, 30.84. Found: $C, 52.00 ; \mathrm{H}, 3.50$.

4-[(3-Ethynyl-2,4,5,6-tetranitro-phenylamino)-methyl]-13-methyl-1-nitro-6,8,9,11,12, 13,14,15,16,17-decahydro-7H-20-oxa-cyclopropa[2,3]cyclopenta[a]phenanthren-17-ol (8) yielding $58 \%$ of product; m.p. $135-137^{\circ} \mathrm{C}$; IR (vmax, $\mathrm{cm}^{-1}$ ) 3400, 3312, 2102, 1350 and 1242: ${ }^{1} \mathrm{H}$ NMR $(300 \mathrm{MHz}$, Chloroform-d) $\delta_{H}: 0.78(\mathrm{~s}, 3 \mathrm{H}), 0.80-1.86(\mathrm{~m}, 9 \mathrm{H}), 2.22-$ $3.64(\mathrm{~m}, 7 \mathrm{H}), 3.92(\mathrm{~s}, 1 \mathrm{H}), 4.82(\mathrm{~m}, 2 \mathrm{H}), 8.12$ (broad, $2 \mathrm{H})$, 6.62-7.12 (m, 4H) ppm. ${ }^{13} \mathrm{C} \mathrm{NMR}\left(300 \mathrm{~Hz}, \mathrm{CDCl}_{3}\right) \delta_{\mathrm{C}}: 15.8$, 24.2, 27.6, 27.7, 30.0, 32.8, 33.7, 37.6, 42.3, 44.3, 50.7, 71.0, 79.70, 82.4, 115.2, 125.1, 126.2, 129.0, 130.6, $132.5,134.8,135.12,136.3,136.5,141.9,142.3$ ppm. ElMS m/z: 6.24.14. Anal. Calcd. for $\mathrm{C}_{27} \mathrm{H}_{24} \mathrm{~N}_{6} \mathrm{O}_{12}: \mathrm{C}, 51.93 ; \mathrm{H}$, 3.87; N, 13.46; O, 30.74. Found: C, 51.88; H, 3.80.

\section{Synthesis of azete derivatives}

In a round bottom flask $(10 \mathrm{ml})$, compounds 7 or 8 (0.50 mmol), 4-Nitrophenylacetonitrile $(85 \mathrm{mg}, 0.52$ mmol), Copperll chloride anhydrous $(67 \mathrm{mg}, 0.50$ $\mathrm{mmol}$ ) and $5 \mathrm{ml}$ of methanol were stirred to room temperature for $48 \mathrm{~h}$. The solvent of mixture was reduced pressure and purified via a crystallization using the methanol:hexane:water (4:2:1) system;

13-Methyl-1-nitro-4-(\{2,3,4,6-tetranitro-5-[2-(4nitro-benzyl)-azet-3-yl]-phenylamino\}-methyl)6,7,8,9,11,12,13,14,15,16-decahydro-20-oxacyclopropa[2,3]cyclopenta[a] phenanthren-17-one (9)

yielding $72 \%$ of product; m.p. $156-158^{\circ} \mathrm{C}$; IR (vmax, $\mathrm{cm}^{-1}$ ) 3312, 1712, 1350 and 1154: ${ }^{1} \mathrm{H}$ NMR $(300 \mathrm{MHz}$, Chloroform-d) $\delta_{H}: 0.92(\mathrm{~s}, 3 \mathrm{H}), 1.20-1.91(\mathrm{~m}, 7 \mathrm{H}), 2.12-$ $3.00(\mathrm{~m}, 8 \mathrm{H}), 3.77(\mathrm{~m}, 2 \mathrm{H}), 4.82$ (broad, $1 \mathrm{H}), 5.70(\mathrm{~s}, 1 \mathrm{H})$, 

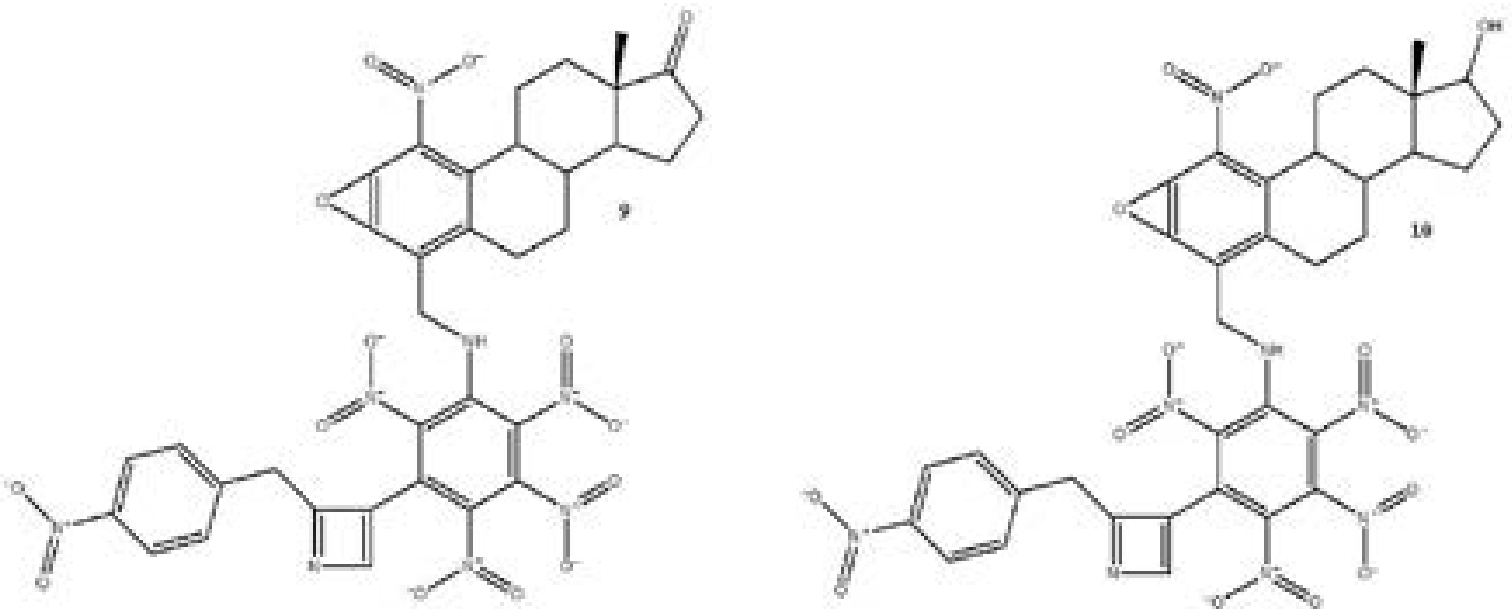

Figure 1. Chemical structure of two azete-steroid derivatives (9 and 10).

7.33-7.92 (m 4H), 9.32 (broad, $1 \mathrm{H})$ ppm. ${ }^{13} \mathrm{C}$ NMR (300 $\left.\mathrm{Hz}, \mathrm{CDCl}_{3}\right) \delta_{\mathrm{c}}:$ 13.8. 21.7, 27.4, 28.1, 30.0, 31.3, 35.3, 37.7, $42.3,44.5,45.2$, 48.1, 50.2, 78.2, 112.6, 114.4, 117.8, $124.1,124.6,125.7,126.0,128.1,128.6,130.2,130.3$, 133.7, 134.4, 135.7, 135.8, 136.3, 137.4, 138.3, 142.0, 146.6, 179.2, 220.3 ppm. El-MS m/z: 784.17. Anal. Calcd. for $\mathrm{C}_{35} \mathrm{H}_{28} \mathrm{~N}_{8} \mathrm{O}_{14}$ : C, 53.58; $\mathrm{H}, 3.60 ; \mathrm{N}, 14.28 ; \mathrm{O}, 28.55$. Found: $\mathrm{C}, 53.50 ; \mathrm{H}, 3.54$

\section{3-Methyl-1-nitro-4-(\{2,3,4,6-tetranitro-5-[2-(4-} nitro-benzyl)-azet-3-yl]-phenylamino\}-methyl)$6,8,9,11,12,13,14,15,16,17-d e c a h y-d r o-7 H-20-o x a-$ cyclopropa[2,3]cyclopenta [a]phenanthren-17-ol (10) yielding $68 \%$ of product; m.p. $172-174^{\circ} \mathrm{C}$; IR (vmax, $\mathrm{cm}^{-1}$ ) 3400, 3312, 1352 and 1154: ${ }^{1} \mathrm{H}$ NMR (300 MHz, Chloroform-d) $\delta_{H}: 0.78(\mathrm{~s}, 3 \mathrm{H}), 0.80-1.86(\mathrm{~m}, 9 \mathrm{H}), 2.20-$ $3.62(\mathrm{~m}, 7 \mathrm{H}), 3.77(\mathrm{~m}, 2 \mathrm{H}), 4.82$ (broad, $1 \mathrm{H}), 5.70(\mathrm{~s}, 1 \mathrm{H})$, 7.33 (m, 2H), 7.86 (broad, 2H), 7.92 (m 2H) ppm. ${ }^{13} \mathrm{C}$ NMR $\left(300 \mathrm{~Hz}, \mathrm{CDCl}_{3}\right) \delta_{\mathrm{C}}: 15.8,24.2,27.7,30.0,32.7,33.7,37.7$, 42.3, 42.3, 44.4, 44.5, 50.7, 82.4, 117.8, 124.1, 124.6, $125.7,126.0,128.1,128.9,130.2,130.6,133.7,134.8$, 135.7, 135.8, 136.3, 137.4, 138.3, 142.0, 146.6, 179.2 ppm. El-MS m/z: 786.18. Anal. Calcd. for $\mathrm{C}_{35} \mathrm{H}_{30} \mathrm{~N}_{8} \mathrm{O}_{14}$ : C, 53.44; H, 3.84; N, 14.24; O, 28.47. Found: C, 53.38; $\mathrm{H}, 3.80$.

\subsection{Physicochemical parameters evaluation}

Some electronic parameters such as HOMO (Highest Occupied Molecular Orbital), LUMO (Lowest Unoccupied Molecular Orbital) energy, orbital coefficients distribution, molecular dipole moment and HBD (hydrogen bond donor groups) and HBA (hydrogen bond acceptor groups) and PSA (polar surface area) were evaluated using the SPARTAN'06 software [20].
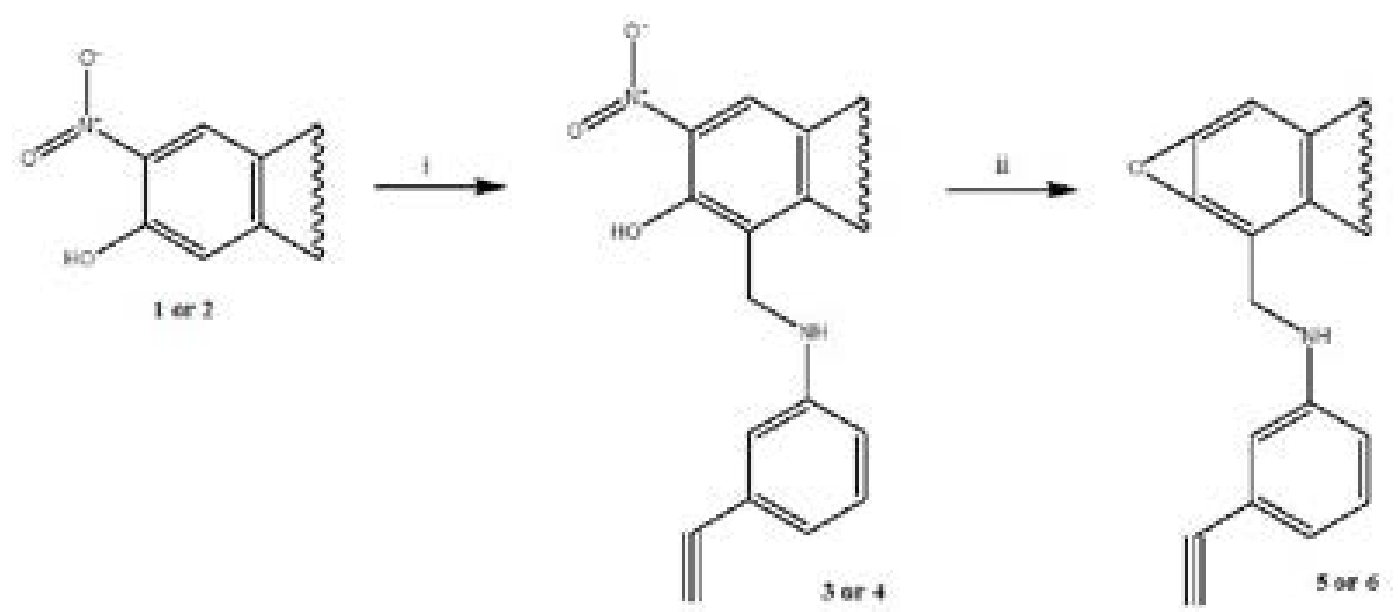

Figure 2. Synthesis of two ether-steroid derivatives ( 5 or 6 ). Reaction of 2-Nitroestrone (1) or 2-Nitroestradiol (2) with 3-Ethynylanyline (i) to form 4-[(3-Ethynyl-phenylamino)-steroid-17-one (3) or 4-[(3-Ethynyl-phenylamino)-steroid-3,17-diol (4). Then, the compound 5 or 6 were prepared via intramolecular displazament of nitrile group involved in the chemical structure from 3 or 4 . ii $=$ dimethyl sulfoxide. 


\section{Pharmacophore evaluation}

The 3D pharmacophore model for the compounds 6 and 7 was determinate using LigandScout 4.08 software [21]

\subsection{Theoretical evaluation of the interaction} between compounds $\mathbf{9}$ or $\mathbf{1 0}$ and aromatase enzyme.

The interaction of compound 4 with aromatase enzyme (2wd3) [22] was carried out using a DockingServer [23].

\section{RESULTS and DISCUSSION}

In this study were prepared two azete-steroid derivatives (Figure 1) from 2-nitroestrone (compound 1) or 2-nitroestradiol (compound 2) using some chemical strategies.

The first stage was achieved for the synthesis of three amino steroids; it is important to mention that several methods have been used to synthesis some amino-steroid derivatives for example, the preparation of $17-\alpha$-amino steroids using a $\omega$-transaminase enzyme from Arthrobacter sp [23]. Other studies showed the synthesis of amino-steroids through a nitro-steroids derivatives reduction [24]. Also, a report showed an amination of steroids using palladium as catalyst [25]. Other data showed the synthesis of some amino-steroid derivatives via Mannich reaction; it is noteworthy that structural chemistry of these compounds [26] involves an activated methyl group in ring $\mathrm{A}$.

In this study, the reactivity of the hydrogen atom involved in ring $\mathrm{A}(\mathrm{C}-4)$ of both compounds 1 or 2 was evaluated using the Mannich reaction. Therefore, 1 or 2 reacted with 3 -ethynyl-aniline in presence of formaldehyde (Figure 2) to form the amino-steroid derivatives (compounds 3 and 4). The results of ${ }^{1} \mathrm{H}$ NMR spectrum for 3 showed several signals at $0.93 \mathrm{ppm}$ for methyl group bound to steroid nucleus; at 1.20-2.50, 3.01 and $7.16 \mathrm{ppm}$ for steroid moiety; at $2.82 \mathrm{ppm}$ for alkyne group; at 4.40 for methylene bound to both amino group and ring $\mathrm{A}$; at 6.56-7.12 ppm for phenyl group; at 9.10 ppm for both hydroxyl and amino groups. The ${ }^{13} \mathrm{C}$ NMR showed several signals at $13.9 \mathrm{ppm}$ for methyl group bound to steroid nucleus; at 21.6-37.2, 47.9-50.4, 123.5125.0 and $134.3-146.7 \mathrm{ppm}$ for steroid moiety; at 42.34 $\mathrm{ppm}$ for methylene group bound to both amino group and ring A; at 78.2-84.0 ppm for alkyne group; at 113.1$122.7,125.0-129.8$ and $147.1 \mathrm{ppm}$ for phenyl group; at $219.8 \mathrm{ppm}$ for ketone group. Finally, the mass spectrum from 3 showed a molecular ion (m/z) 444.53.

Other results showed several signals involved in the ${ }^{1} \mathrm{H}$ NMR spectrum for 4 at $0.64 \mathrm{ppm}$ for methyl group; at 0.80-2.52, 2.94-3.64 and 7.64 ppm for steroid moiety; at $2.84 \mathrm{ppm}$ for alkyne group; at $4.40 \mathrm{ppm}$ for methylene bound to amino group and ring A; at 6.62-7.10 for phenyl group; at $8.20 \mathrm{ppm}$ for both hydroxyl and amino groups. The ${ }^{13} \mathrm{C}$ NMR showed several signals at 13.8 ppm for methyl bound to steroid nucleus; at 24.2-37.2, 44.2-50.7, 86.4, 123.5, 125.3, 134.8-145.4 and 147.1 ppm for steroid moiety; at $42.3 \mathrm{ppm}$ for methylene bound to amino group and ring $\mathrm{A}$; at 78.2-84.0 ppm for alkyne group; at 113.1-122.7, 125.00, 129.8 and 147.0 ppm for phenyl group; at 220.3 ppm for ketone group.
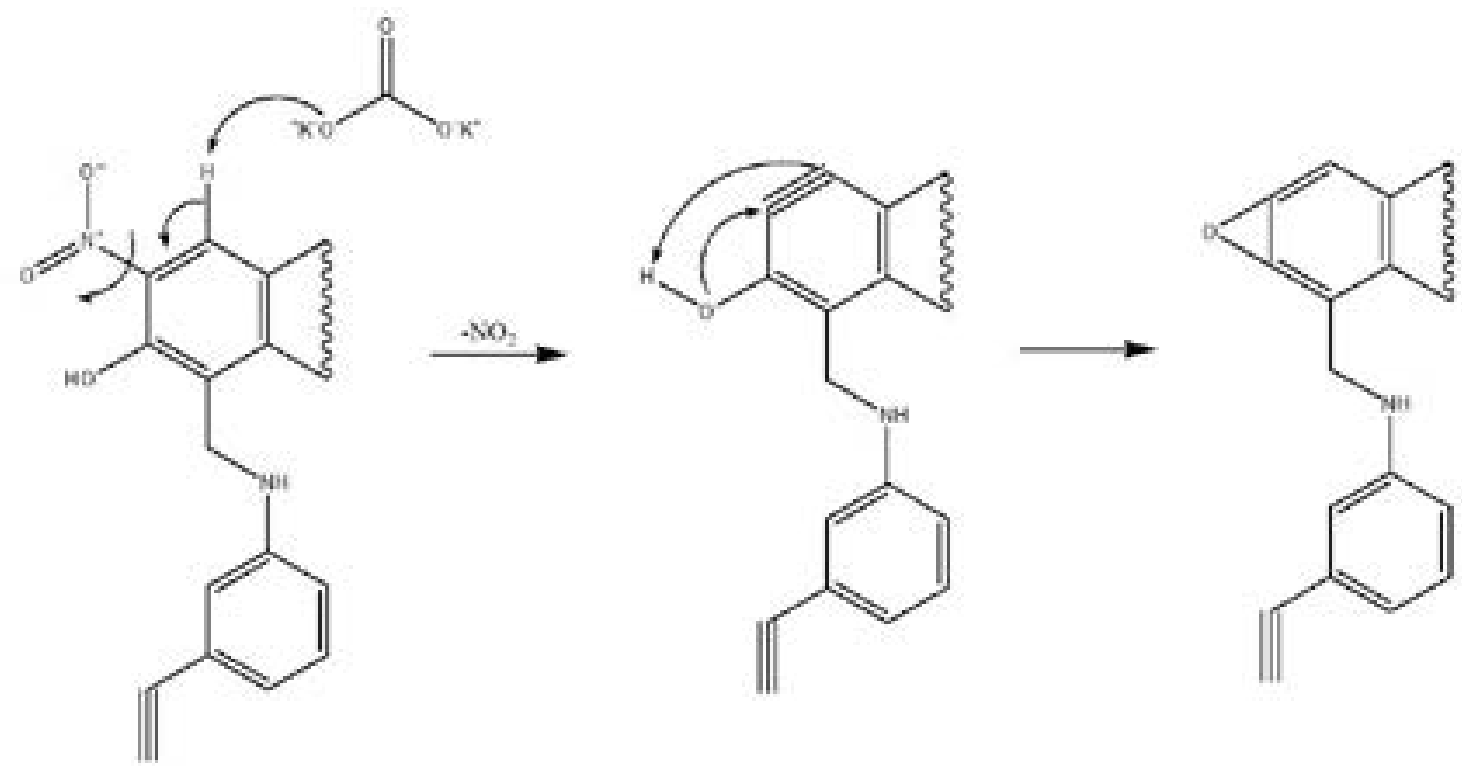

Figure 3. Reaction mechanism of synthesis of compounds 5 or 6 . 

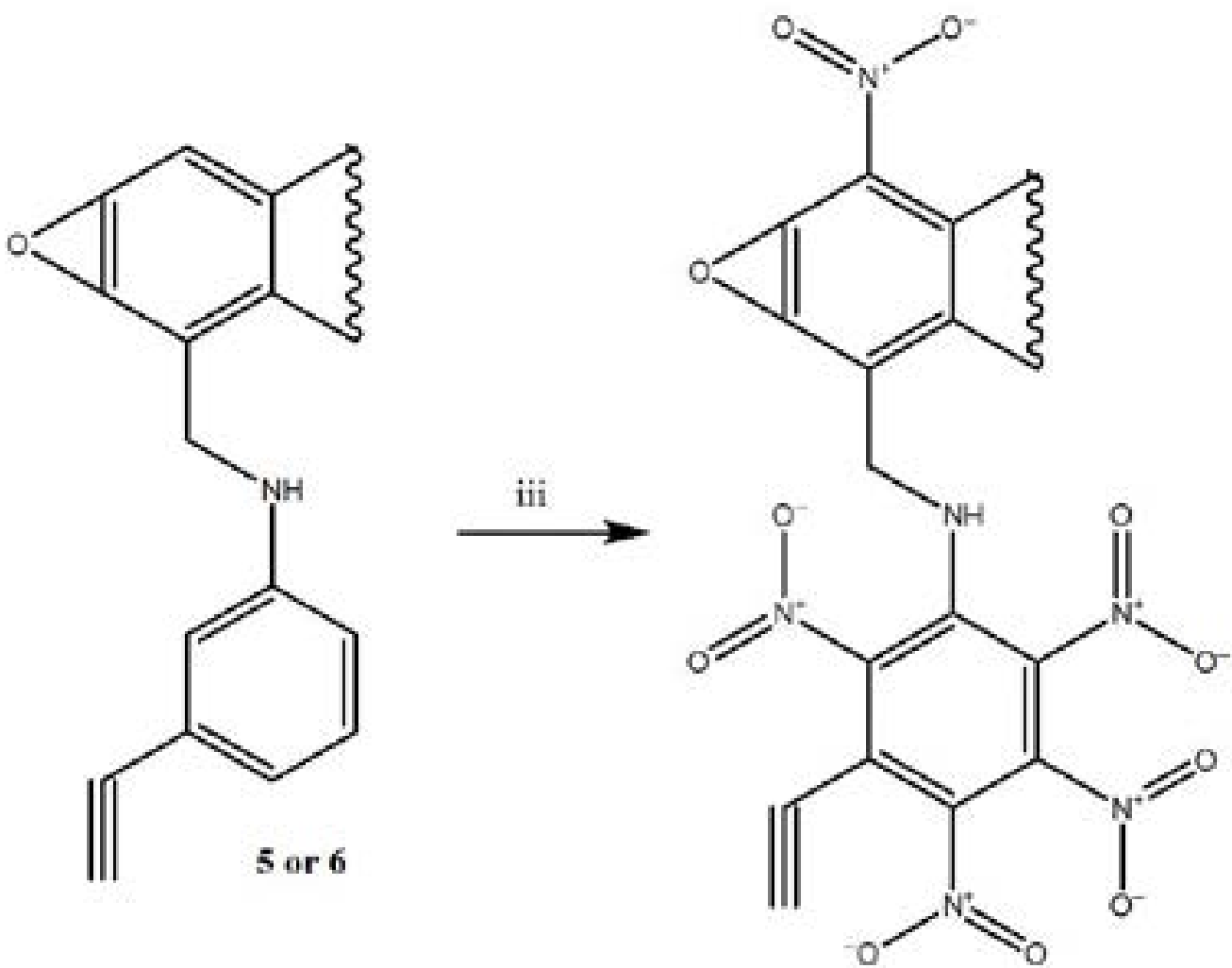

\section{7 or 8}

Figure 4. Synthesis of two tetranitro-phenylamino)-1-nitro-steroid derivatives (7 or 8). Nitration of two ether-steroid derivatives (5 or 6) with $\mathrm{HNO} 3 /(\mathrm{CH} 3 \mathrm{CO}) 2 \mathrm{O}$ (iii) to form 7 or 8 .

In addition, the mass spectrum from 4 showed a molecular ion (m/z) 446.22.

\section{Etherification of $\mathbf{3}$ or $\mathbf{4}$}

Several studies showed the preparation of ether groups using some reagents such as (E)-alk-2-en-ol [27], $\mathrm{CuCl}$ [28], $\mathrm{Cu}(\mathrm{AcO})_{2}$ [29], $\mathrm{PhCOOH}$ [30]. In addition, there are some methods to the synthesis of ether groups, via displacement of nitro groups using dipolar aprotic solvents [31]. Analyzing these data, in this study, two ether-steroid derivatives (compound 5 or 6 ) were prepared using a previously method reported via intramolecular displacement of the nitro group from compounds 3 and 4 in the presence of dimethyl sulfoxide (Figure 2). In addition, the formation of 5 or 6 involves an cyclohexa-1,3dien-5-yne as intermediary (Figure 3).

The results of ${ }^{1} \mathrm{H}$ NMR spectrum for 5 showed several signals at $0.90 \mathrm{ppm}$ for methyl group bound to steroid nucleus; at 1.20-2.54 and 6.22 ppm for steroid moiety; at 4.48 ppm for methylene group bound to both amino and A-ring of steroid; at $2.88 \mathrm{ppm}$ for alkyne group; at $4.73 \mathrm{ppm}$ for amino group; at 6.62-7.16 ppm for phenyl group. The ${ }^{13} \mathrm{C}$ NMR displayed several signals at $13.8 \mathrm{ppm}$ for methyl group bound to steroid nucleus; at 21.7-35.7, 47.4-50.5, 109.8, 118.3 and 131.9-147.4 ppm for steroid moiety; at 38.44 ppm for methylene bound to both amino and A-ring; at 78.2-84.0 ppm for alkyne group; at 113.1, 122.5-129.8 and 148.5 ppm for phenyl group; at 220.70 for ketone group. Finally, the mass spectrum from 5 showed a molecular ion (m/z) 397.20.

Other results showed several signals involved in the ${ }^{1} \mathrm{H}$ NMR spectrum for 6 at 0.76 ppm for methyl group bound to steroid nucleus; at 0.82-2.54, 3.64 and 6.16 ppm for steroid moiety; at $2.88 \mathrm{ppm}$ for alkyne group; at $4.48 \mathrm{ppm}$ for methylene bound to both amino and A-ring; at 5.58 ppm for both hydroxyl and amino groups; at 6.62-7.16 ppm for phenyl group. The ${ }^{13} \mathrm{C}$ NMR showed several signals at 15.82 ppm for methyl group bound to steroid nucleus; at 

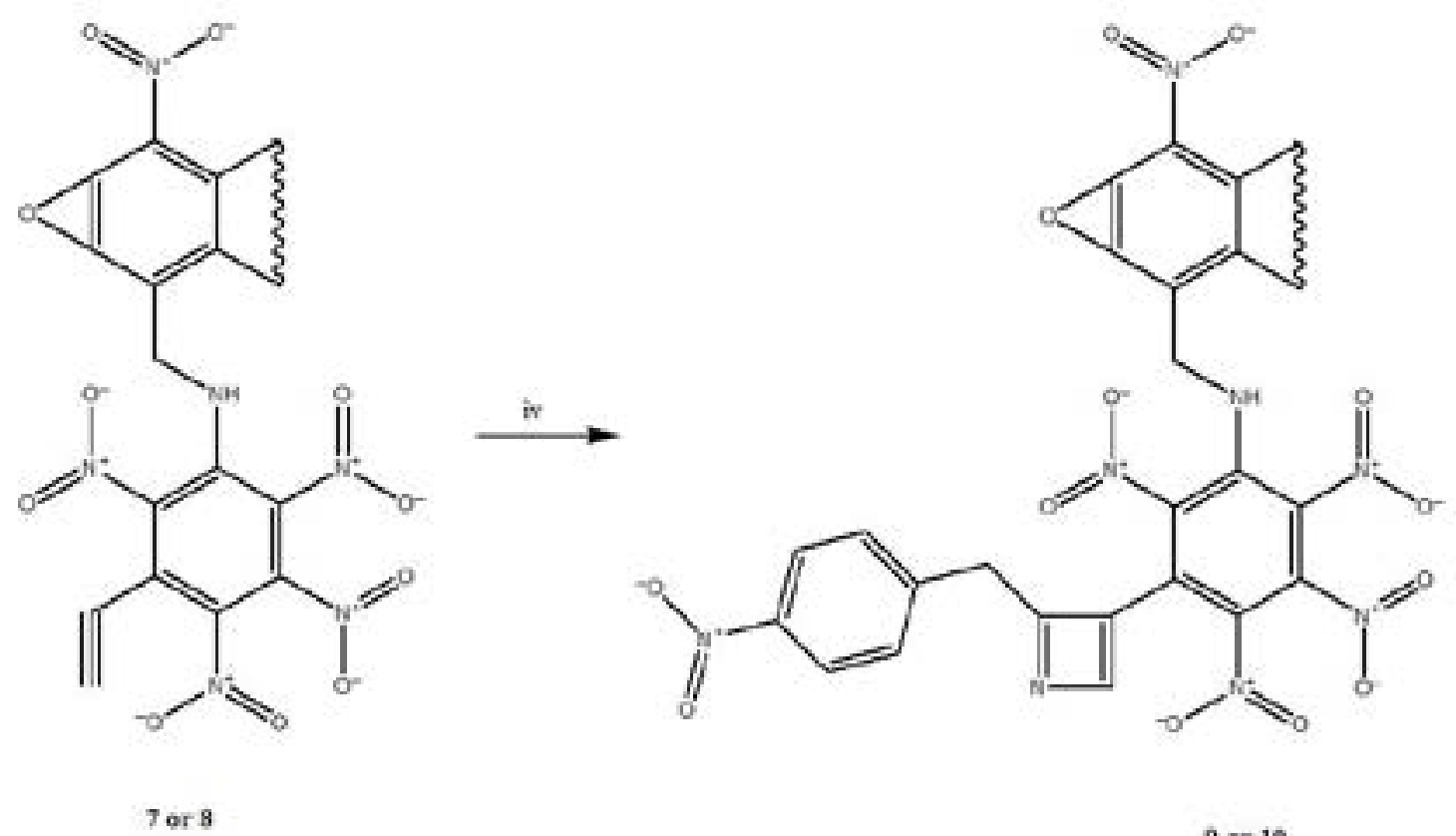

9 or 10

Figure 5. Preparation of two azete-steroid derivatives (9 or 10). Reaction of 7 or 8 with 4-Nitrophenylacetonitrile to form 9 or 10 using Copperll (iv) as catalyst.

24.2-37.2, 44.4-50.7, 82.4, 110.2, 118.3 and 132.3-147.4 ppm for steroid moiety; at 38.4 ppm for methylene bound to both amino group and A-ring; at 78.21 and 84.00 for alkyne group; at 113.14, 122.5-129.8 and 148.5 ppm for phenyl group. Additionally, the mass spectrum from 6 showed a molecular ion (m/z) 399.21.

\section{Nitration of 5 or $\mathbf{6}$}

There are several report in the literature for preparation of nitro derivatives usin g some reagents such as $\mathrm{WO}_{3} /$ $\mathrm{ZrO}_{2}$ (32), $\mathrm{NO}_{2}$ [33], $\mathrm{HNO}_{3} /$ montmorillonite [34], $\mathrm{NH}_{4} \mathrm{NO}_{3}$ and $\left(\mathrm{CF}_{3} \mathrm{CO}\right)_{2} \mathrm{O}$ [35], $\mathrm{BF}_{3}$ [36], $\mathrm{HNO}_{3} / \mathrm{H}_{2} \mathrm{SO}_{4}$ [37] and others. In this study, compounds 7 or 8 (Figure 4) were prepared through of nitration of phenyl groups involved in the chemical structure of 5 or 6 with $\mathrm{HNO}_{3} /\left(\mathrm{CH}_{3} \mathrm{CO}\right)_{2} \mathrm{O}$. The ${ }^{1} \mathrm{H}$ NMR spectrum for 7 showed several at $0.92 \mathrm{ppm}$ for methyl group bound to steroid nucleus; at 1.20-3.00 ppm for steroid moiety; at 3.90 ppm for alkyne group; at 4.84 ppm for methylene bound to both amino and phenyl groups; at 9.92 for amino group. The ${ }^{13} \mathrm{C}$ NMR displayed several signals at $13.8 \mathrm{ppm}$ for methyl group bound to steroid nucleus; at 21.7-37.7, 45.2-50.2, 126.2-130.2, 134.4, 136.3 and 141.9 ppm for steroid moiety; at 42.3 ppm for methylene bound to both amino and phenyl groups; at 71.079.7 ppm for alkyne group; at 115.2-125.1, 132.5, 135.1, 136.5 and $142.3 \mathrm{ppm}$ for phenyl group; at $220.30 \mathrm{ppm}$ for ketone group. Finally, the mass spectrum from 7 showed a molecular ion (m/z) 6.22.12.
Other results showed several signal involved in the ${ }^{1} \mathrm{H}$ NMR spectrum for 8 at 0.78 ppm for methyl group bound to steroid nucleus; at 0.80-3.64 ppm for steroid moiety; at 3.92 ppm for alkyne group; at 4.82 ppm for methylene bound to both amino and phenyl groups; at 8.12 ppm for both hydroxyl and amino groups. The ${ }^{13} \mathrm{C}$ NMR showed several signals at $15.8 \mathrm{ppm}$ for methyl group; at 24.2-37.6, 44.350.7, 82.4, 126.2-130.6, 134.8, 136.3 and 141.9 ppm for steroid moiety; at $42.3 \mathrm{ppm}$ for methylene bound to both amino and phenyl groups; at 71.0-79.7 ppm for alkyne group; at 115.2-125.2, 132.5, 135.1, 136.5 and 142.3 ppm for phenyl groups. Additionally, the mass spectrum from 8 showed a molecular ion (m/z) 624.14.

\section{Formation of Azete Derivatives (compound 9 or 10)}

Several oxazete-derivatives have been synthetized using some reagents such as mesitonitrile oxide [38], $\alpha, \alpha$-bis(alkylthio) oxime [39], acylisothiocyanate [40] and others. In this investigation, two azete derivatives were prepared via reaction $2+2$ addition of compounds 7 or 8 and 1-Nitro-4-prop-2-ynyl-benzene using Copperll chloride as catalyst (Figures 5 and 6).

The ${ }^{1} \mathrm{H}$ NMR spectrum for 9 (Figure 7) at $0.92 \mathrm{ppm}$ for methyl group bound to steroid nucleus; at 1.20-3.00 ppm for steroid moiety; at 3.77 for methylene bound to both phenyl group and azete ring; at $4.82 \mathrm{ppm}$ for methylene 
Fint souze<smiles>O=[N+]([O-])c1ccc(CP2CCCC2)cc1</smiles><smiles>C=CC(=CCC)CC</smiles>

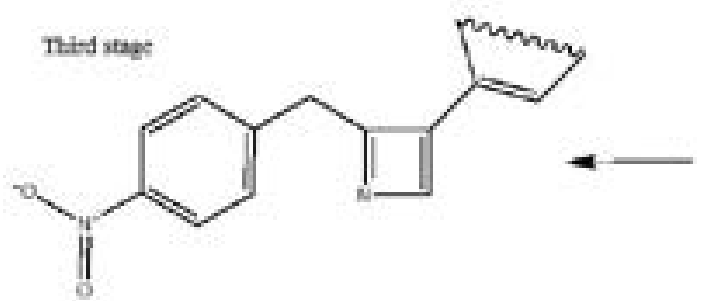

Figure 6. Reaction mechanism of synthesis of compounds 9 or 10.

bound to both amino and phenyl group; at $5.70 \mathrm{ppm}$ for azete ring; at 7.33-7.92 ppm for phenyl group; at 9.32 for amino group.

The ${ }^{13} \mathrm{C}$ NMR displayed several signals at $13.8 \mathrm{ppm}$ for methyl group; at 21.7-37.7, 45.2-50.2, 124.1, 128.6, $130.3,134.4,136.3$ and 142.0 ppm for steroid moiety; at $42.3 \mathrm{ppm}$ for methylene bound to both phenyl and amino groups; at $44.5 \mathrm{ppm}$ for methylene bound to phenyl group and azete ring; at 117.8, 138.3 and $179.2 \mathrm{ppm}$ for azete ring; at 124.6-128.1, 130.2, 133.7, 135.7-135.8, 137.4 and $146.6 \mathrm{ppm}$ for phenyl groups; at 220.30 for ketone group. Additionally, the mass spectrum from 9 showed a molecular ion (m/z) 784.17.

Finally, the ${ }^{1} \mathrm{H}$ NMR spectrum for 10 (Figure 8) showed several signals at $0.78 \mathrm{ppm}$ for methyl group bound to steroid nucleus; at 0.80-3.62 ppm for steroid moiety; at $3.77 \mathrm{ppm}$ for methylene bound to both phenyl group and azete ring; at $4.82 \mathrm{ppm}$ for methylene bound to both amino and phenyl groups; at 5.70 ppm for azete ring; at 7.36 and 7.92 ppm for phenyl group; at 7.86 ppm for both hydroxyl and amino groups.

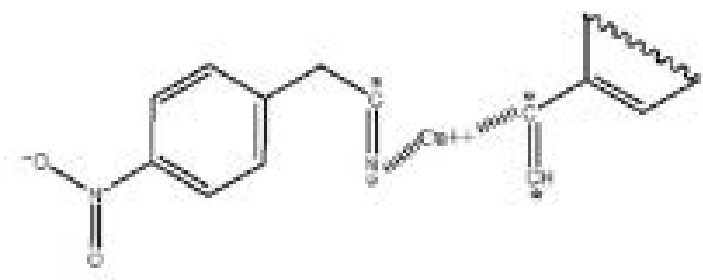

The ${ }^{13} \mathrm{C}$ NMR showed several signals at $15.8 \mathrm{ppm}$ for methyl group; at 24.2-37.7, 42.3-44.4, 50.7-82.4, 128.9, $130.6,134.8,136.3$ and 142.0 ppm for steroid moiety; at $42.3 \mathrm{ppm}$ for methylene bound to both amino and phenyl groups; at $44.5 \mathrm{ppm}$ for methylene bound to both phenyl group and azete ring; at 117.8, 138.32 and 179.2 ppm for azete ring; at 124.1-128.1, 130.2, 133.7, 135.8, 137.4 and 146.6 ppm for phenyl groups. Additionally, the mass spectrum from 10 showed a molecular ion $(\mathrm{m} / \mathrm{z}) 786.18$.

\section{Electronic Parameters}

There are some studies which indicate that molecular orbitals and frontier electron density are used to predict the most reactive position in some electron system on several types of reactions $[41,42]$.These studies suggest that values of highest occupied molecular orbital (HOMO), lowest unoccupied molecular orbital (LUMO) and their energy gap reflect the chemical activity of a molecule [43].

Here, it is important to mention, that, some methods have been developed to evaluate the relation between HOMO and LUMO with biological activity of some 


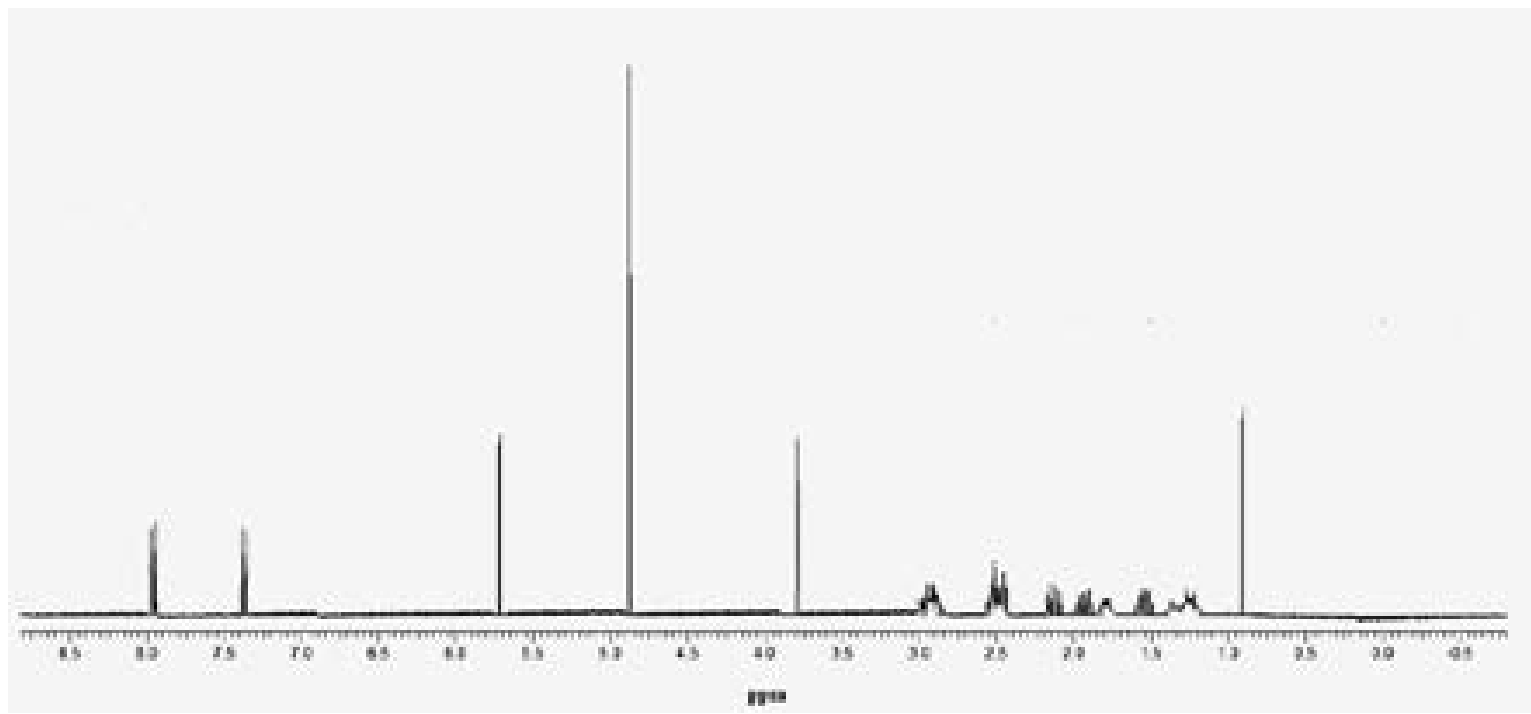

Figure 7. The scheme showed ${ }^{1} \mathrm{HNMR}$ spectrum from compound 9. The spectrum was analyzed with a Varian VXR300/5 FT NMR apparatus at $300 \mathrm{MHz}$ in $\mathrm{CDCl} 3$. Axis abscissa (ppm). ppm = parts per million.

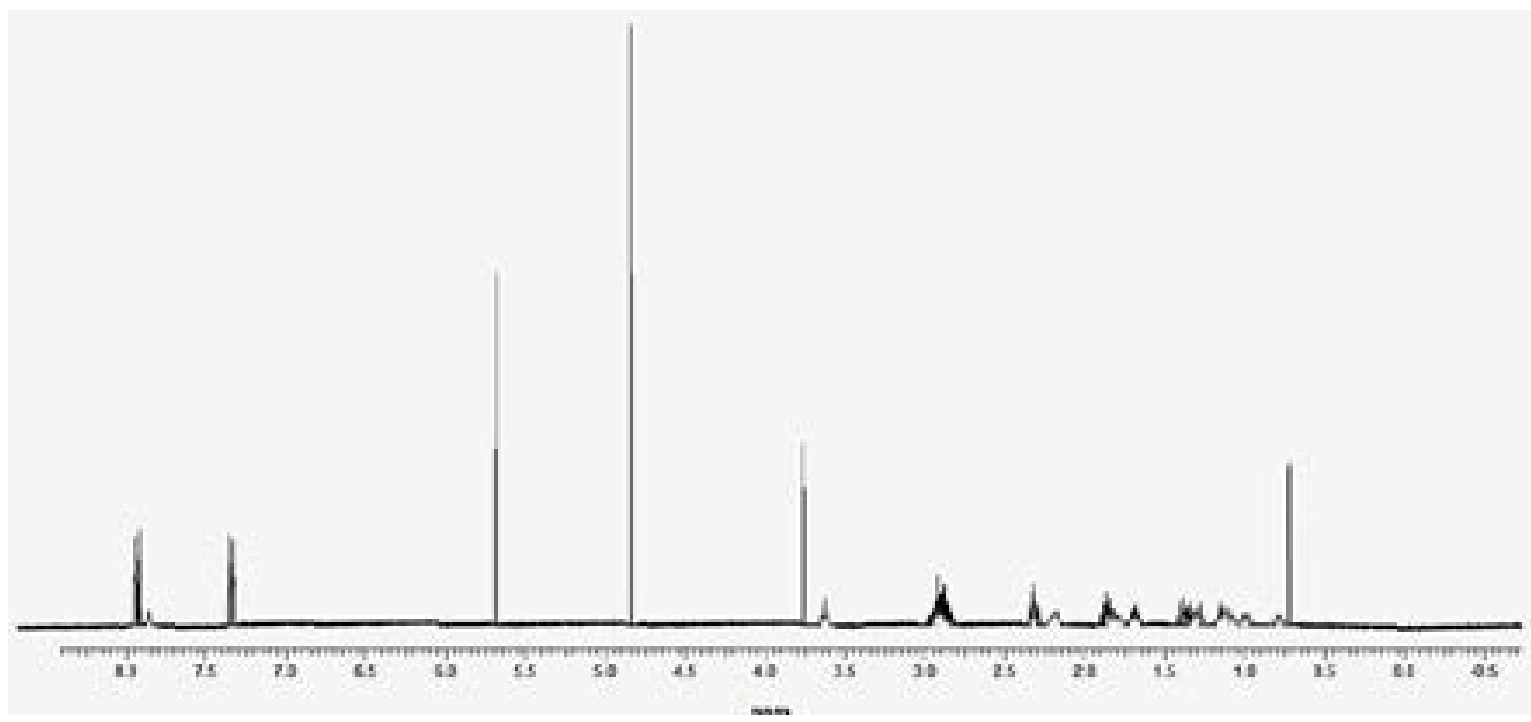

Figure 8. The scheme showed ${ }^{1}$ HNMR spectrum from compound 10 . The spectrum was analyzed with a Varian VXR300/5 FT NMR apparatus at $300 \mathrm{MHz}$ in $\mathrm{CDCl}_{3}$. Axis abscissa (ppm). ppm = parts per million.

Table 1. Physicochemical parameters involve in the structure of compounds 9 and 10.

\begin{tabular}{ccc}
\hline Parameters & C-9 & C-10 \\
\hline Polarizability $\left(\mathrm{cm}^{3}\right)$ & 93.12 & 93.52 \\
\hline PSA A2 & 240.23 & 244.82 \\
\hline LogP & -1.38 & -1.87 \\
\hline Energy $(\mathrm{au})$ & -2605.54 & -2606.72 \\
\hline HBD & 1 & 2 \\
\hline HBA & 19 & 19 \\
\hline HOMO $(\mathrm{eV})$ & -8.46 & -8.49 \\
\hline LUMO $(\mathrm{eV})$ & -1.68 & -1.66 \\
\hline
\end{tabular}

HBD (hydrogen bond donors); HBA (hydrogen bond acceptors); PSA (polar surface area). 
compounds; for example, there are some data which showed the evaluation of the frontier molecular orbitals (HOMO-LUMO gap) from some steroid using MINDO and ZINDO models [44, 45]. In this study, the Hartee-Fock method (method of approximation for the determination of the wave function and the energy of a quantum many-body system in a stationary state) was used to determinate both HOMO and LUMO orbitals (Figure 9 and Table 1) in Spartan'06 V112 program [46].

The results showed changes in both $\mathrm{HOMO}$ and LUMO values for the compound 9 compared with 10; this phenomenon could be conditioned by the difference in $\pi$ orbitals density that is located in chemical structure 9 and 10

\section{Pharmacophore Ligand Model}

For several years, some chemical models have been used to determine the three-dimensional orientation adopted by the functional groups of a molecule to predict its interaction with several biomolecules [46]; for example, the use of a pharmacophore model which can furnish a new insight to design novel molecules that can enhance or inhibit the function of a biological target which can be useful in new drug discovery. Analyzing this premise in this study, the LigandScout software [47] was used to develop a pharmacophore model for compounds 9 and 10 (Figure 10).

The results showed that functional groups involved in the compounds 9 and 10 could interact via hydrophobic contacts or as hydrogen bond acceptors or as hydrogen bond donor with some biomolecules.

\section{Interaction Theoretical (Protein-Ligand)}

Analyzing the hypothesis mentioned above and some reports which suggest that the formation of binary complexes between some compounds that act as ligands with several target biomolecules could induce changes in many activities of some biological systems [48-53]; Therefore, in this study, was carried out a theoretical analysis on the interaction of both compound 9 or 10 with Dwd3 protein using exemestane and anastrozole (aromatase inhibitors) [54] as a control in a Doc-

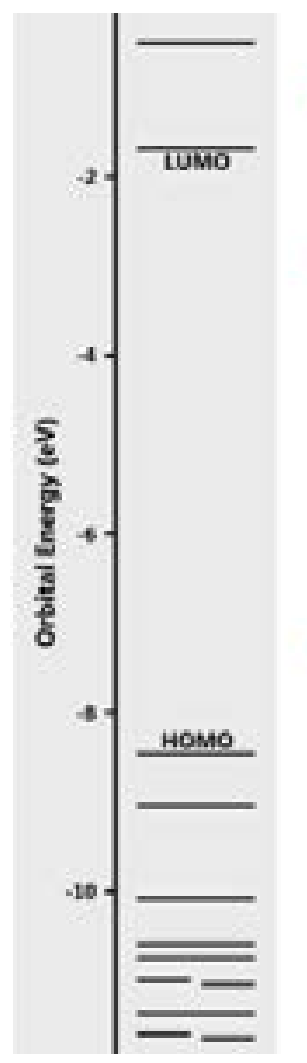

$-8.46 \mathrm{eV}$

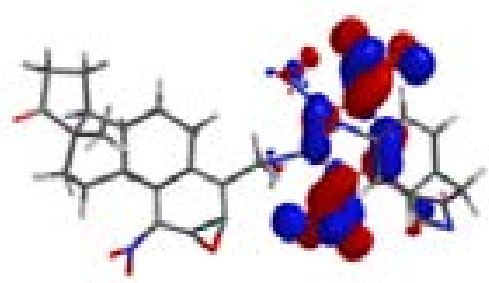

$-1.66 \mathrm{~N}$

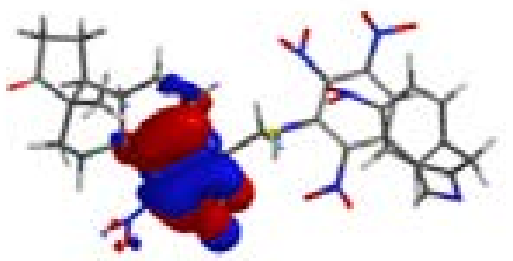

$-4.425$

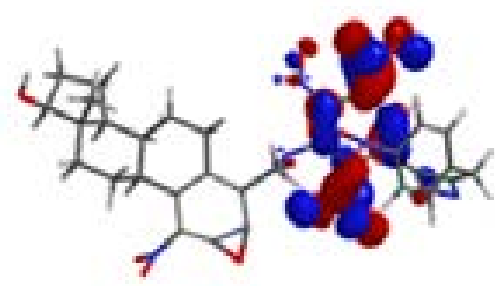

los ever

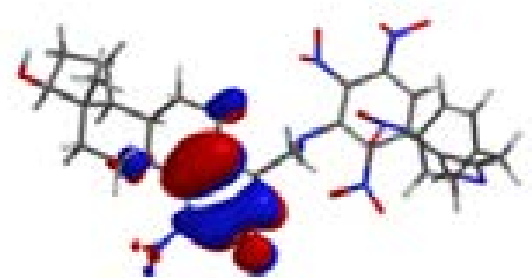

Figure 9. Molecular orbitals (HOMO and LUMO) involved in the compounds 9 (I) and 10 (II). Visualized with SPARTAN'06 software 


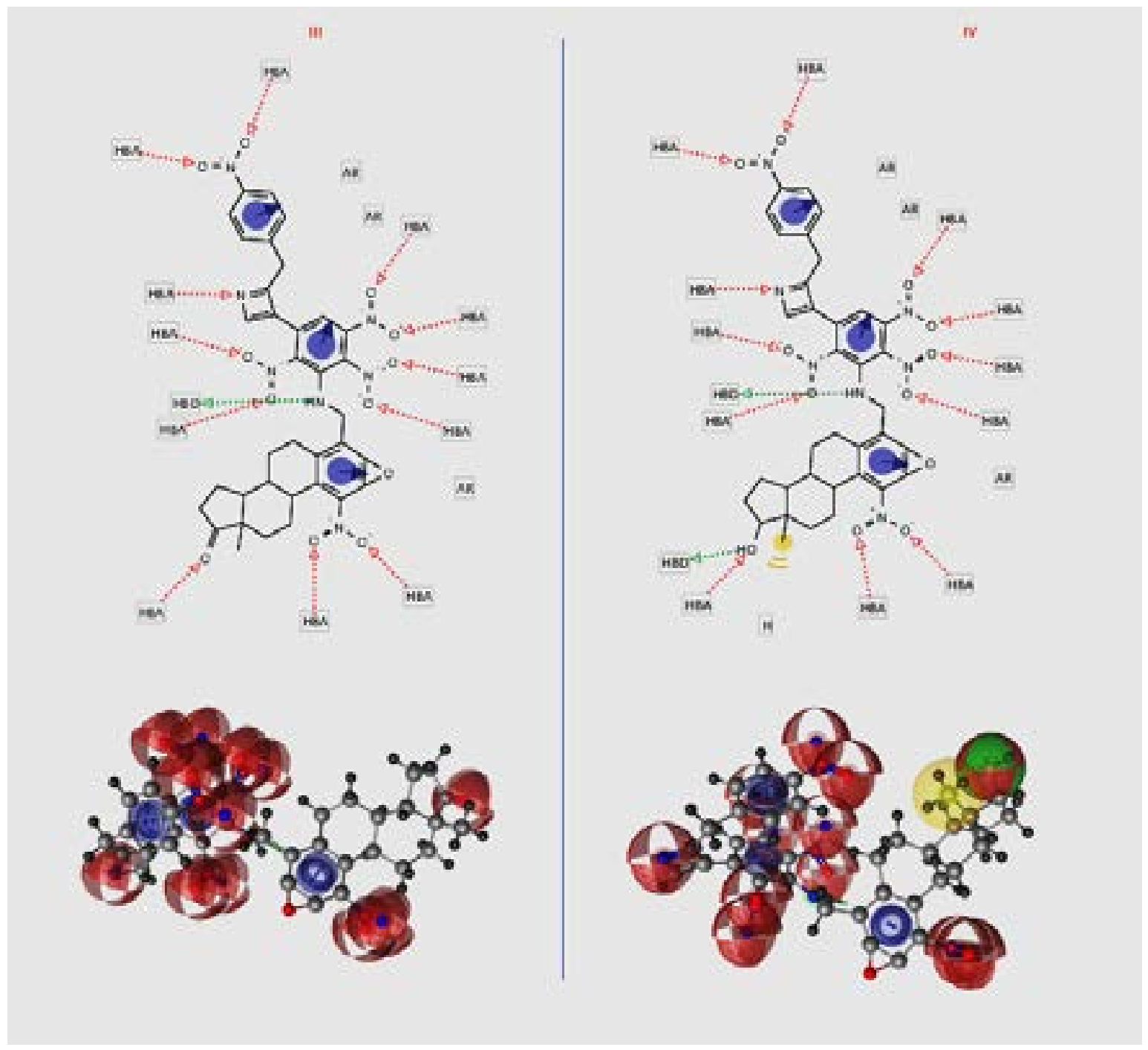

Figure 10. Theorethical pharmacophore from both compounds 9 (III) and 10 (1V) using the LigandScout software. The model involves a methyl group (yellow) hydrogen bond acceptors (HBA, red) and hydrogen bond donor (HBD, green).

kingServer [23]; here, it is important to mention that Dockingserver was used because we believe that it is one of the most complete to analyze the protein-drug interaction.

The data (Table 2) showed differences in the interaction of both compounds 9 and 10 with some aminoacid residues involved in $2 \mathrm{wd} 3$ protein surface. In addition, other data suggest that there is another type of aminoacid residues in the interaction of both exemestane and anastrozole with $2 \mathrm{Wd} 3$. This phenomenon could be conditioned by the different conformations adopted by both compound 9 and 10 or the length of bound between the steroid-derivatives and the aminoacid residues involved in $2 \mathrm{Wd} 3$ protein surface. However, it is impor- tant to mention that some reports suggest that other thermodynamic factors such as free energy of binding, electrostatic energy, total intermolecular energy and Van der Waals (vdW) + hydrogen bond (Hbond) + desolvation energy can be involved in the interaction of several compounds with the proteins or enzymes $[25,26]$.

\section{Thermodinamic Parameters}

Analyzing the hypothesis above mentioned, in this study, some thermodynamic parameters were determinate using DockigServer [23]. Theoretical data (Table 3) indicates that there are differences in the thermodynamic parameters of exametane and anastrazole compared with both compounds 9 and 10. However, the theoretical results showed that inhibition constant (Ki) 
involved in the interaction of both compounds 9 and 10 with 2WD3 protein surface was lower compared with exametane and anastrazole.

All these results suggest that both compounds 9 and 10 could exert a higher interaction with the $2 \mathrm{Wd} 3$ protein surface of, which can be translated as a decrease in aromatase activity.

\section{CONCLUSIONS}

In this study, is reported a facile synthesis of two steroid derivatives using several chemical strategies. In addition, the theoretical interaction of steroid derivatives ( 9 or 10) with the aromatase enzyme indicate that both compounds 9 and 10 could act as aromatase enzyme inhibitors which can be translated as good candidates for their evaluation in some cancer model; Nnevertheless, possibly the compound 10 could have higher activity against aromatase enzyme. However, to demonstrate

Table 2. Aminoacids residues involved in the interaction of anastrazole, exametane and compounds 9 (C-9) and 10 (C-10) with 2WD3 protein surface.

\begin{tabular}{|c|c|c|c|}
\hline Anastrazole & Exametane & $C-9$ & $C-10$ \\
\hline $\mathrm{Gln}_{92}$ & $\operatorname{Trp}_{5}$ & $\operatorname{Trp}_{5}$ & $\operatorname{Trp}_{5}$ \\
\hline $\mathrm{His}_{94}$ & $\mathrm{His}_{64}$ & Leu $_{60}$ & $\mathrm{Asn}_{62}$ \\
\hline $\mathrm{Val}_{121}$ & $\mathrm{Ala}_{65}$ & Asn $_{62}$ & $\mathrm{Asn}_{67}$ \\
\hline Phe $_{130}$ & $\mathrm{His}_{94}$ & $\mathrm{His}_{64}$ & $\mathrm{Glu}_{69}$ \\
\hline $\mathrm{Val}_{134}$ & $\mathrm{His}_{119}$ & $\mathrm{Glu}_{69}$ & $\| e_{91}$ \\
\hline Leu $_{140}$ & $\mathrm{Val}_{121}$ & $\mathrm{His}_{94}$ & $\operatorname{Gln}_{92}$ \\
\hline Leu $_{197}$ & $\mathrm{Val}_{142}$ & $\mathrm{Phe}_{130}$ & $\mathrm{His}_{94}$ \\
\hline $\operatorname{Thr}_{199}$ & Leu $_{197}$ & $\operatorname{Thr}_{199}$ & $\mathrm{Val}_{121}$ \\
\hline \multirow[t]{4}{*}{$\mathrm{PrO}_{201}$} & $\mathrm{Thr}_{198}$ & $\mathrm{PrO}_{201}$ & Phe $_{130}$ \\
\hline & $\mathrm{Thr}_{199}$ & & Pro $_{201}$ \\
\hline & $\mathrm{Val}_{206}$ & & \\
\hline & $\operatorname{Trp}_{208}$ & & \\
\hline
\end{tabular}

GIn (glutamine); His (histidine); Val (valine); Leu (leucine); Thr (threonine);

Pro (proline); Ala (alanine); Trp (tryphtophan); Asn (aspartic acid); Glu (glutamine);

Phe (phenylalanine); Ile (Isoleucine).

Table 3. Thermodynamic parameters involved in the interaction of anastrazole, exametane and compounds 9 (C-9) and 10 (C-10) with 2WD3 protein surface.

\begin{tabular}{|c|c|c|c|}
\hline Compound & $\begin{array}{l}\text { Est. Free Energy of Binding } \\
\text { (Kcal/mol) }\end{array}$ & $\begin{array}{l}\text { Est. Inhi-bition Constant, Ki } \\
\qquad(\mu \mathrm{M})\end{array}$ & $\mathrm{cdW}+\mathrm{Hbond}+$ desolv Energy \\
\hline Anastrazole & -5.11 & 180.06 & -6.92 \\
\hline Exametane & -8.39 & 710.67 & -8.36 \\
\hline C-9 & -7.08 & 6.42 & -7.11 \\
\hline
\end{tabular}

Table 4. Thermodynamic factors involved in the interaction of anastrazole, exametane and compounds 9 (C_9) and 10 (C-10) with 2WD3 protein surface.

\begin{tabular}{cccc}
\hline Compound & Electrost. Energy & Total Inter-molec. Energy & Interact. Surface \\
\hline Anastrazole & -0.01 & -6.92 & 666.43 \\
\hline Exametane & -0.03 & -8.39 & 648.45 \\
\hline C-9 & -0.01 & -7.11 & 828.06 \\
\hline C-10 & 0.02 & -8.83 & 927.79 \\
\hline
\end{tabular}


this, experimental analyzes would have to be done in some biological model.

\section{ACKNOWLEDGEMENTS}

The authors extend their sincere thanks to Dr. Cindy Rossina Saravia, Rector of the Autonomous University of Campeche for their support in carrying out this study.

\section{CONFLICT OF INTEREST}

On behalf of all authors, the corresponding author states that there is no conflict of interest.

\section{References}

1. M.D. Pegram, G.E. Konecny. C. O'Callaghan, M. Beryt. R. Pietras. D.J. Slamon, Rational combinations of trastuzumab with chemotherapeutic drugs used in the treatment of breast cancer, J. Natl. Cancer Inst., 96 (2004) 739-749.

2. K.C. Chu, C.A. Lamar, H.P. Freeman, Racial disparities in breast carcinoma survival rates: separating factors that affect diagnosis from factors that affect treatment, Cancer. 97 (2003) 2853-2860.

3. B.N. Polite, O.I. Olopade, Breast cancer and race: a rising tide does not lift all boats equally, Perspect Biol Med., 48 (2005) 166-175.

4. R.T. Chlebowski, Z. Chen, G.L. Anderson, T. Rohan, A. Aragaki, D. Lane, L.L. Adams, Ethnicity and breast cancer: factors influencing differences in incidence and outcome, J. Natl. Cancer Inst., 97 (2005) 439-448.

5. L.J. Pierce, L.F. Hutchins, S.R. Green, D.L. Lew, J.R. Gralow, R.B. Livingston, K.S. Albain, equencing of tamoxifen and radiotherapy after breast-conserving surgery in early-stage breast cancer, J. Clin. Oncol., 23 (2005) 24-29.

6. B. Gerber, A. Krause, T. Reimer, I. Mylonas, J. Makovitzky, W. Janni, Anastrozole versus tamoxifen treatment in postmenopausal women with endocrine-responsive breast cancer and tamoxifen-induced endometrial pathology, Clin. Cancer Res., 12 (2006) 1245-1250.

7. M. Colleoni, W. Luo, P. Karlsson, J. Chirgwin, S. Aebi, G. Jerusalem, C. Kamby, Extended adjuvant intermittent letrozole versus continuous letrozole in postmenopausal women with breast cancer (SOLE): a multicentre, open-label, randomised, phase 3 trial, Lancet Oncol., 19 (2018) 127-138.

8. S. De Placido, C. Gallo, M. De Laurentiis, G. Bisagni, G. Arpino, M.G. Sarobba, F. Cognetti, Adjuvant anastrozole versus exemestane versus letrozole, upfront or after 2 years of tamoxifen, in endocrine-sensitive breast cancer (FATAGIM3): a randomised, phase 3 trial, Lancet Oncol., 19 (2018) 474-485.

9. P. Brožič, P. Kocbek, M. Sova, J. Kristl, S. Martens, J. Adamski, T.L. Rižner, Flavonoids and cinnamic acid derivatives as inhibitors of $17 \beta$-hydroxysteroid dehydrogenase type 1 , Mol. Cell Endocrinol., 301 (2009) 229-234.

10. M. Salah, A.S. Abdelsamie, M. Frotscher, Inhibitors of 17 $\beta$-hydroxysteroid dehydrogenase type 1, 2 and 14: Structures, biological activities and future challenges, Mol. Cell Endocrinol., 18 (2018) 0303-7207.

11. G. Yang, S. Nowsheen, K. Aziz, A.G. Georgakilas, Toxicity and adverse effects of Tamoxifen and other anti-estrogen drugs, Pharmacol. Therapeut., 139 (2013) 392-404.
12. J.E. Lester, D. Dodwell, O.P. Purohit, S.A. Gutcher, S.P. Ellis, R. Thorpe, R.E. Coleman, Prevention of anastrozole-induced bone loss with monthly oral ibandronate during adjuvant aromatase inhibitor therapy for breast cancer, Clin. Cancer Res., 14 (2008) 6336-6342.

13. M.C. Yang, C. Peng, H. Huang, L. Yang, X.H. He, W. Huang, H. Cui, B. Han, Organocatalytic Asymmetric Synthesis of Spiro-oxindole Piperidine Derivatives That Reduce Cancer Cell Proliferation by Inhibiting MDM2-p53 Interaction, Org. Lett., 19 (2017) 6752-6755.

14. B. Su, S. Landini, D.D. Davis, R.W. Brueggemeier, Synthesis and biological evaluation of selective aromatase expression regulators in breast cancer cells, J. Med. Chem., 50 (2007) 1635-1644.

15. C. Ding, Y. Zhang, H. Chen, Z. Yang, C. Wild, N. Ye, C. Ester, A. Xiong, M. White, Q. Sheng, J. Zhou, Oridonin ring A-based diverse constructions of enone functionality: identification of novel dienone analogues effective for highly aggressive breast cancer by inducing apoptosis, J. Med. Chem., 56 (2013) 1-31.

16. T. Akama, Y. Shida, T. Sugaya, H. Ishida, K. Gomi, M. Kasai, Novel 5-aminoflavone derivatives as specific antitumor agents in breast cancer, J. Med. Chem., 39 (1996) 3461-3469.

17. P. Dandawate, E. Khan, S. Padhye, H. Gaba, S. Sinha, J. Deshpande, S. Venkateswara, M. Khetmalas, A. Ahmad, F. Sarkar, Synthesis, characterization, molecular docking and cytotoxic activity of novel plumbagin hydrazones against breast cancer cells, Bioorg. Med. Chem. Lett., 22 (2012) 3104-3108.

18. G. Macindoe, L. Mavridis, V. Venkatraman, M. Devignes, D. Ritchie, HexServer: an FFT-based protein docking server powered by graphics processors, Nucleic acids Res., 38 (2010) W445-W449.

19. Stander, F. Joubert, A. Joubert, Docking, synthesis, and in vitro evaluation of antimitotic estrone analogs, Chem. Biol. Drug Des., 77 (2011) 173-181.

20. N. Nishimura, K. Kobayashi, Self-Assembly of a CavitandBased Capsule by Dynamic Boronic Ester Formation, Ang. Chem. Int. Ed., 47 (2008) 6255-6258.

21. V. Temml, T. Kaserer, Z. Kutil, P. Landa, T. Vanek, D. Schuster, Pharmacophore modeling for COX-1 and-2 inhibitors with LigandScout in comparison to Discovery Studio, Future Med. Chem., 6 (2014) 1869-1881.

22. L. Woo, T. Jackson, A. Putey, G. Cozier, P. Leonard, K. Acharya, B. Potter, Highly potent first examples of dual aromatasesteroid sulfatase inhibitors based on a biphenyl template, J. Med. Chem., 53 (2010) 2155-2170.

23. E. Hazai, S. Kovács, L. Demkó, Z. Bikádi, DockingServer: molecular docking calculations online, Acta Pharm. Hung., 79 (2009) 17-21.

24. N. Richter, R. Simon, W. Kroutil, J. Ward, H. Hailes, Synthesis of pharmaceutically relevant $17-\alpha$-amino steroids using an $\omega$-transaminase, Chem. Commun., 50 (2014) 6098-6100.

25. T. Curran, G. Flynn, D. Rudisill, P. Weintraub, A novel route to a 4-amino steroid: MDL 19687, Tetrahedron Lett., 36 (1995) 4761-4764.

26. A. Averin, E. Ranyuk, N. Lukashev, S. Golub, A. Buryak, I. Beletskaya, Palladium-catalyzed amination in the synthesis of macrocycles comprising cholane, polyamine and pyridine units, Tetrahedron Lett., 49 (2008) 1188-1191.

27. L. Figueroa, F. Díaz, M. Rosas, E. García, E. Pool, A. Camacho, M. López, R. García, A facile synthesis and theoretical analysis of a steroid-cyclophano, Lett. Org. Chem., 12 (2015) 614-621. 
28. R.S. Lankalapalli, J.T. Eckelkamp, D. Sircar, D.A. Ford, P.V. Subbaiah, R. Bittman, Synthesis and antioxidant properties of an unnatural plasmalogen analogue bearing a trans O-vinyl ether linkage, Org. Lett., 11 (2009) 2784-2787.

29. E. Buck, Z.J. Song, D. Tschaen, P.G. Dormer, R.P. Volante, P.J. Reider, Ullmann diaryl ether synthesis: Rate acceleration by 2, 2, 6, 6-tetramethylheptane-3, 5-dione, Org. Lett., 4 (2002) 1623-1626.

30. T.D. Quach, R.A. Batey, Copper (II)-catalyzed ether synthesis from aliphatic alcohols and potassium organotrifluoroborate salts, Org. Lett., 5 (2003) 1381-1384.

31. K.L. Zheng, M.Q. You, W.M. Shu, Y.D. Wu, A.X. Wu, AcidMediated Intermolecular [3+ 2] Cycloaddition toward Pyrrolo [2, 1-a] isoquinolines: Total Synthesis of the Lamellarin Core and Lamellarin G Trimethyl Ether, Org. Lett., 19 (2017) 2262-2265.

32. L. Figueroa, F. Diaz, M. Rosas, G. Maldonado, E. García E. Pool, Design and synthesis of some carbamazepine derivatives using several strategies, Lett. Org. Chem., 12 (2015) 394-401.

33. V.V. Brei, S.V. Prudius, O.V. Melezhyk, Vapour-phase nitration of benzene over superacid $\mathrm{WO}_{3} / \mathrm{ZrO}_{2}$ catalysts, Appl. Catal. A., 239 (2003) 11-16.

34. H. Sato, K. Hirose, Vapor-phase nitration of benzene over solid acid catalysts (1): Nitration with nitric oxide ( $\left.\mathrm{NO}_{2}\right)$, Appl. Catal. A., 174 (1998) 77-81.

35. H. Sato, K. Hirose, K. Nagai, H. Yoshioka, Y. Nagaoka, Vapor phase nitration of benzene over solid acid catalysts: II. Nitration with nitric acid (1); montmorillonite and mixed metal oxide catalysts, Appl. Catal. A., 175 (1998) 201-207.

36. J.V. Crivello, Nitrations and oxidations with inorganic nitrate salts in trifluoroacetic anhydride, J. Org. Chem., 46 (1981) 3056-3060.

37. G.A. Olah, H.C. Lin, Aromatic substitution. XXXV. Boron trifluoride catalyzed nitration of benzene, alkylbenzenes, and halobenzenes with methyl nitrate in nitromethane solution, J. Am. Chem. Soc., 96 (1974) 2892-2898.

38. M.A. Paul, Ortho-para directive effects for aromatic nitration in acetic anhydride, J. Am. Chem. Soc., 80 (1958) 5332-5333.

39. T. Matsumoto, N. Tokitoh, R. Okazaki, First oxazagermete: synthesis, structure and thermal cycloreversioninto a germanone, Chem. Commun., 16 (1997) 1553-1554.

40. H.L. Corkins, L. Storace, E.R. Osgood, A new route to the $4 \mathrm{H}$ 1,2 -oxazete ring system by the stereospecific oxidation of (Z)-3, 3-dimethyl-1, 1-bis (methylthio)-2-butanone oxime, Tetrahedron Lett., 21 (1980) 2025-2028.
41. W. Walter, W. Ruback, 2,2,4-Trisubstituted 2H-1, 3Oxazetes-A New Type of Heterocycles-A Reinvestigation, Liebigs Ann. Chem., 2 (1982) 231-239.

42. K.N. Houk, Frontier molecular orbital theory of cycloaddition reactions, Acc. Chem. Res., 8 (1975) 361-369.

43. D.H. Ess, K.N. Houk, Theory of 1, 3-dipolar cycloadditions distortion/interaction and frontier molecular orbital models, J. Am.Chem. Soc., 130 (2008) 10187-10198.

44. Y.R. Prasa, P.R. Kumar, D.J. Smiles, P.A. Babub, QSAR studies on chalcone derivatives as antibacterial agents against Bacillus pumilis, Arkivok., 11 (2008) 266-276.

45. J.N. Latosińska, J. Kasprzak, Z. Kazimierczuk, Effects of chlorination and deoxiribose substitution on electron density distribution in indazole molecule studied by $35 \mathrm{Cl}$ NQR spectroscopy and ab initio calculations, J. Mol. StrucTHEOCHEM., 530 (2000) 217-222.

46. L. Figueroa, F. Díaz, E. Garcia, Synthesis of Two steroids derivatives and its relationship with some physicochemical parameters, J. Chem., 9 (2012) 27-34.

47. N. Obi-Egbedi, I. Obot, M. El-Khaiary, S. Umoren, E. Ebenso, Computational Simulation and Statistical Analysis on the Relationship Between Corrosion Inhibition Efficiency and Molecular Structure of Some Phenanthroline Derivatives on Mild Steel Surface, Int. J. Electrochem. Sci., 6 (2011) 56495675.

48. D. Seeliger, B.L. de Groot, Ligand docking and binding site analysis with PyMOL and Autodock/Vina, J. Computer-Aided Mol. Des., 24 (2010) 417-422.

49. M.L. Verdonk, V. Berdini, M.J. Hartshorn, W.T. Mooij, C.W. Murray, R.D. Taylor, P. Watson, Virtual screening using protein- ligand docking: avoiding artificial enrichment, J. Chem. Inf. Comp. Sci., 44 (2004) 793-806.

50. S.Y. Huang, X. Zou, Advances and challenges in proteinligand dockin, Int. J. Mol. Sci., 11 (2010) 3016-3034.

51. M. Shalbafan, G. Rezaei Behbehani, H. Ghasemzadeh, Study of interaction of human serum albumin with doxorubicin (anti-cancer drug) by docking simulation, Chem. Methodol., 3 (2019)348-353.

52. R.K. Bommeraa, R. Merugu, L. Eppakayala, A Facile Synthesis and Docking Studies of N-(3-(4-Chlorophenoxy) benzyl)2-methyl-7H-pyrrolo [2, 3-d] pyrimidin-4-amine, Chem. Methodol., 3 (2019) 354-361.

53. J. Jays, S. Mohan, J. Saravanan, Molecular docking studies of novel aminopyrimidines as potent antifungal agents, Chem. Methodol., 3 (2019) 442-450.

54. S. Chumsri, T. Howes, T. Bao, G. Sabnis, A. Brodie, Aromatase, aromatase inhibitors, and breast cancer, J. Steroid Biochem. Mol. Biol., 125 (2011) 13-22. 